\title{
Physical Map of the Bacteriophage P22 Genome
}

\author{
JoAn E. RUtila AND ETHEl NOLAND JACKSON ${ }^{1}$ \\ Department of Microbiology and Immunology, University of Michigan, Ann Arbor, Michigan 48109
}

Received April 3, 1981; accepted May 29, 1981

\begin{abstract}
P22 mutations have been located relative to restriction endonuclease cleavage sites on the P22 chromosome by rescue of genetic markers from cloned DNA fragments. These data, in combination with prior genetic and physical mapping data, have allowed the construction of a detailed composite physical and genetic map.
\end{abstract}

Many cleavage sites for restriction endonucleases have now been mapped on the chromosome of bacteriophage P22 (1-5). This physical map of cleavage sites facilitates generation of defined genome segments for a variety of applications. Many such applications require information about the location of genes relative to restriction sites. In previous work, we have oriented the genetic map of P22 with the restriction endonuclease cleavage site map and located some mutations relative to certain restriction targets in the late region of the P22 genome (4). Comparison of the resulting physical gene map with the preexisting genetic map shows that the recombination frequency map is distorted in the late region and gives a poor approximation of physical locations of genes on the chromosome $(4,6)$. In the present studies, we have mapped more mutations relative to additional cleavage sites to give a higher resolution map of the late region. We have also correlated physical and genetic sites in portions of the early region not included in the previous study. The combination of these results defines a more detailed physical gene map of the P22 genome.

In order to integrate the genetic and physical maps, P22 wild type DNA was cleaved with restriction endonucleases and the resulting fragments were inserted into

\footnotetext{
${ }^{1}$ To whom requests for reprints should be addressed.
}

the plasmid vector $\mathrm{pBR322}$ (Table 1). The resulting plasmids were introduced into Salmonella typhimurium. Genetic procedures were then applied to define what P22 genes were present on each cloned fragment. S. tuphimurium strains containing no amber suppressor and carrying plasmids having known P22 DNA restriction fragment inserts were used as lawns for plating various $P 22$ amber mutant strains. Since the infection is carried out under nonpermissive conditions only those phage that have been able to recombine with wild type cloned P22 sequences or that have been complemented by plasmid-encoded P22 proteins will form plaques. Therefore an increase in plating efficiency of a P22 amber mutant strain on an $\mathrm{Su}^{-}$host carrying a cloned P22 DNA fragment indicates the fragment carries the wild type allele of the amber mutation. Representative data for this type of experiment have been reported previously (4). The results of such plating tests for many mutants on strains containing cloned fragments (Table 1) are summarized in Fig. 1. The physical map coordinates for the restriction sites that define these cloned P22 fragments (Table 1) are listed in Table 2.

Markers in the nonessential ant $(7,8)$ gene were mapped by infecting permissive cells carrying a plasmid with P22 ant ${ }^{-}$ mutant strains and allowing one cycle of lytic growth before harvesting the lysate. The fraction of wild type recombinant phage in the lysate was then determined 
(a)

EcoRI
PstI
SolI/ECORI

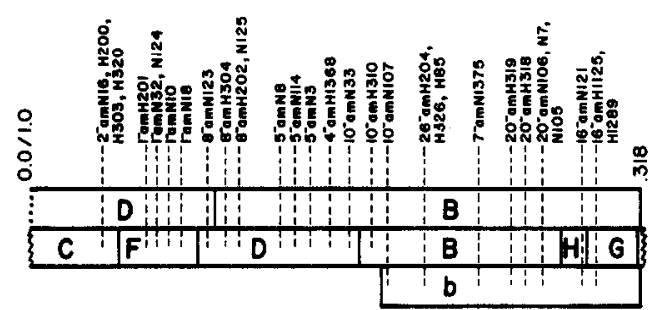

(b)

\section{EcoRI \\ EcoRI/BamHI EcoRI/Hind III}

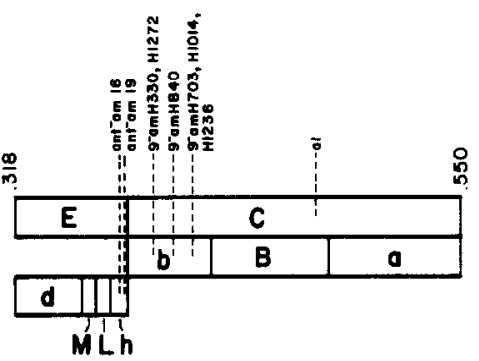

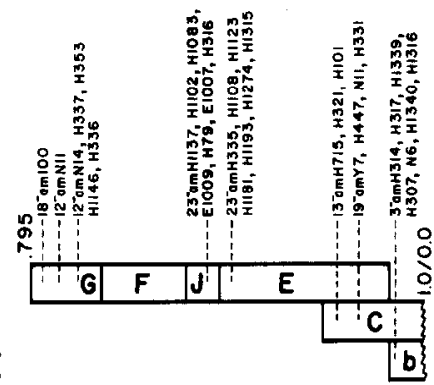

FIG. 1. P22 genes were located relative to restriction endonuclease cleavage sites by rescue of the wild type marker from restriction fragments of P22 DNA cloned in the plasmid vector pBR322. Markers in essential genes were located by plating $\mathrm{P} 22$ amber mutant strains on $\mathrm{Su}^{-} S$. typhimurium NK1345 carrying either pBR322 or a plasmid containing cloned P22 sequences (the hybrid plasmids used are listed in Table 1). Plating efficiencies of all the P22 am strains on NK1345 carrying pBR322 range from $10^{-5}$ to $10^{-7}$, relative to the $\mathrm{Su}^{+}$host. An increase in plating efficiency of $10^{2}-10^{5}$ on NK1345 containing one of the hybrid plasmids (Table 1) indicates the wild type allele of the amber mutation is present on the cloned P22 DNA fragment (see reference (4) for representative plating efficiency data). Mutations in nonessential genes were located by infecting liquid cultures of permissive cells carrying cloned P22 sequences with the phage mutant to be tested. The lysate produced after a single round of infection was titered on both permissive and nonpermissive hosts to determine the relative number of wild type recombinant progeny (see Table 3). Mutant phage strains used were from the collection of $D$. Botstein unless otherwise indicated. Results of the marker rescue experiments are summarized in the figure. The locations of P22 amber markers are shown relative to restriction endonuclease sites on P22 DNA. Dashed lines connect a mutation with all lettered P22 fragments from which the wild type allele was rescued. The position of mutations within a restriction fragment is not to scale. Each of several alleles associated with a single dashed line has been rescued from the indicated DNA fragments, but the order of alleles within the group is unknown. Physical site coordinates of restriction endonuclease cleavage sites are given in Table 2. (a) Physical gene map of PZ2 DNA between coordinates 0 and 0.318 . Fragment D is formed by EcoRI cleavage at 0.096 and DNA maturation at pac (20). The order of the mutations in gene 1 (9), gene 8 (F. Winston and D. Botstein, unpublished experiments), gene 5 (9), and gene 20 (P. B. Berget, G. Weinstock, and D. Botstein, manuscript in preparation) has been determined previously. Amber alleles in genes 10 and 16 were ordered by these experiments. (b) Physical gene map of P22 
TABLE 1

P22 DNA FRAGMENTS CLONED IN pBR322 ${ }^{a}$

\begin{tabular}{llll}
\hline Plasmid & \multicolumn{1}{c}{$\begin{array}{c}\text { Cloned P22 } \\
\text { fragment }\end{array}$} & Plasmid & \multicolumn{1}{c}{$\begin{array}{c}\text { Cloned P22 } \\
\text { fragment }\end{array}$} \\
\hline pP22-314 & IIindIII G & pP22-451 & SaII/EcoRI a \\
pP22-318 & HindIII F & pP22-201 & EcoRI/BamHI b \\
pP22-322 & HindIII J & pP22-250 & BamHI B \\
pP22-312 & HindIII E & pP22-512 & PstI C \\
pP22-384 & EcoRI/HindIII b & pP22-513 & PstI F \\
pP22-3 & EcoRI D & pP22-508 & PstI D \\
pP22-4 & EcoRI B & pP22-515 & PstI B \\
pP22-6 & EcoRI E & pP22-502 & PstI H \\
pP22-10 & EcoRI C & pP22-514 & PstI G \\
\hline
\end{tabular}

${ }^{a}$ The restriction endonuclease fragments of P22 c1-7 DNA listed were inserted into the plasmid vector pBR322 and the hydrid plasmids were used in marker rescue studies to yield the maps given in Fig. 1. Construction of the hybrid plasmids containing EcoRI, EcoRI/SalI, EcoRI/BamHI (4), HindIII and HindIII/ $E c o R I$ (5) fragments has been described previously. The PstI cleavage site map of P22 DNA was generated and PstI fragments inserted into pBR322 by A. Siegel, R. Deans, and E. Jackson (unpublished experiments). All plasmids were initially introduced into Escherichia coli. Plasmid DNA was prepared from the $E$. coli clones and used to transform $S$. typhimurium LT2 $\mathrm{r}^{-} \mathrm{m}^{-}$hisC527am cysA1348am (DB5289, obtained from D. Botstein) or S. typhimurium LT2 $\mathrm{r}^{-} \mathrm{m}^{+} g a l^{+} r i f^{\mathrm{R}} n a l^{\mathrm{R}} c y s^{-}$(NK1345, obtained from N. Kleckner) as described previously (4).

as described in Table 3. The P22 nonessential antigen conversation gene $a 1$ was mapped relative to restriction sites by a cell agglutination assay (see Fig. 1c).

By these approaches, various P22 genes have been mapped relative to physical markers on the chromosome. These results are summarized in Fig. 1. Many of the mutations used in this study have been ordered previously by genetic mapping procedures $(3,7-14)$ and the order of markers determined by our experiments agrees with the earlier results. However, amber mutations in gene 10 have not been

DNA between coordinates 0.318 and 0.550 . Rescue of alleles of gene ant which is not essential for lytic growth is described in Table 3. The ant ${ }^{-}$am alleles used have been ordered, the $a n t^{-} a m 19$ allele being the most carboxyl-terminal ant ${ }^{-}$amber known $(8,13)$. The $9^{-}$am alleles were ordered (P. B. Berget, G. Weinstock, and D. Botstein, manuscript in preparation; 15) by using a series of prophage deletion mutants. The $9^{-}$am 3330 and $\mathrm{H} 1272$ alleles are in the most amino-terminal group while the $9^{-}$amH703, H1014, and H1236 alleles are in the most carboxyl-terminal group of $9^{-}$amber mutations. The region ( $a 1)$ which codes for a prophage-directed modification of the host 0 antigen was mapped to the EcoRI C fragment by an agglutination test (10, 25). NK1345 cells containing the $E c o$ RI $C$ insert in pBR322 were found to be agglutinated by antisera ( $O$ antisera factor 1 , Difco) directed against the modified $\mathrm{O}$ antigen (factor 1 ). Similar tests done with cells containing cloned $B a m H I$ B or $E c o$ RI/BamHI fragment a were negative for factor 1. (c) Physical gene map of P22 DNA between coordinates 0.795 to 1 . The most amino-terminal mutation known in gene 12 is $12^{-}$am N11, and the $12^{-}$alleles N14, H336, H337, H353, H1146 make up the most carboxyl-terminal of eight groups of $12^{-}$alleles mapped by marker rescue from P22 prophage deletion strains (3). Each of the two groups of $23^{-} \mathrm{am}$ alleles (from the collections of T. Poteete and D. Botstein) defined by our experiments probably include independent isolations of mutations at the same site (M. Susskind, unpublished experiments). Since the PstI C and HindIII/EcoRI b fragments span the pac site (at coordinate 0) only a portion of each of these fragments is shown. Gene 3-am alleles are shown on the opposite side of the pac site from gene 2 since these $3^{-}$am alleles were rescued from the EcoRI/HindIII b fragment and not from the smaller subfragment, $E$ coRI D, which has an end at pac (1). However, we cannot exclude the possibility that gene 3 markers lie within EcoRI $\mathrm{D}$ too close to the end of the insert to yield detectable numbers of recombinants. 


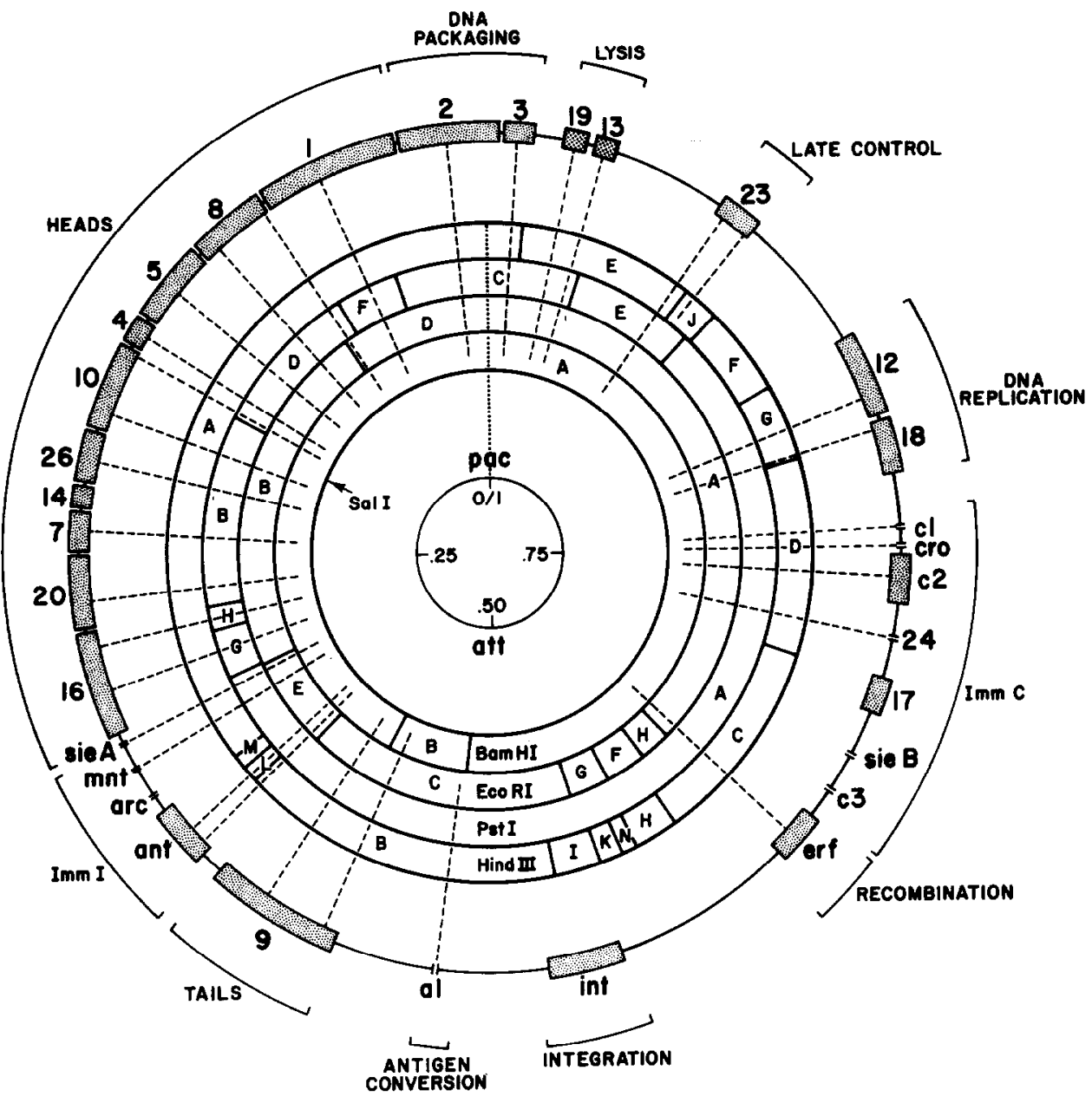

FIG. 2. The physical map of the P22 genome shows the approximate location of genes relative to restriction enzyme cleavage sites. Because mature linear P22 DNA molecules are circularly permuted, the cleavage map is circular (1). Physical map coordinates, indicated on the inner circle, are fractions of the length of one complete set of genes $(41.6 \mathrm{~kb}, 1)$. Pac is the site at which headful packaging of P22 DNA initiates and att is the prophage attachment site $(16,17,20,26)$. The fragment maps shown as four concentric rings are produced by digestion with $B a m H I(3,4) ; E c o R I ~(1,4,20$; fragment D is a segment of EcoRI A generated by DNA maturation at pac); PstI ( 5 , A. Siegel, R. Deans, and E. Jackson, unpublished experiments); and HindIII $(2,29)$. The position of the single cleavage site for $\operatorname{Sall}(3,4)$ is indicated by an arrow. The approximate physical map locations of P22 genes are shown on the outer ring as shaded bars of length proportional to the size of the protein encoded (27), or as short parallel lines where the protein size is unknown. Dashed lines from a gene intersect those restriction fragments known to include at least a portion of the gene. Gene order and gene functions have recently been reviewed (14). Three additional genes, 14 (27), arc (13), and cro (28) are shown here. Genes from the DNA replication region counterclockwise through the antigen conversion region have been assigned to restriction fragments by marker rescue from cloned fragments (Fig. 1; Table 3; 4 ), except for sieA and $m n t$ which were located by assaying expression of the genes from cloned fragments (J. Rutila and E. Jackson, manuscript in preparation). Insertions in ant were shown to lie in HindIII L (2), so HindIII site 3 lies in gene ant (see Fig. 1). Weinstock and Botstein (6) have mapped $\mathrm{Tn} 1$ insertions in genes 20, 16, ant, 9, and the $a 1$ region relative to $E c o R I$ and $B a m H I$ sites, and their conclusions are in agreement with this map. Missense mutations (P. B. Berget, G. Weinstock, and D. Botstein, manuscript in preparation) and insertions within gene 9 (6) have been mapped in the BamHI B fragment, indicating that gene 
TABLE 2

Physical Map Coordinates of Restriction Endonuclease Cleavage Sites on P22 DNA ${ }^{a}$

\begin{tabular}{cccc}
\hline $\begin{array}{c}\text { Restriction } \\
\text { endonuclease } \\
\text { cleavage site }\end{array}$ & $\begin{array}{c}\text { Map } \\
\text { coordinate }\end{array}$ & $\begin{array}{c}\text { Restriction } \\
\text { endonuclease } \\
\text { cleavage site }\end{array}$ & $\begin{array}{c}\text { Map } \\
\text { coordinate }\end{array}$ \\
\hline EcoRI & 0.096 & HindIII & \\
1 & 0.318 & 1 & 0.353 \\
2 & 0.376 & 2 & 0.360 \\
3 & 0.550 & 3 & 0.368 \\
4 & 0.576 & 4 & 0.530 \\
5 & 0.603 & 5 & 0.554 \\
6 & 0.623 & 6 & 0.566 \\
7 & & 7 & 0.596 \\
$P s t$ I & 0.045 & 9 & 0.699 \\
1 & 0.087 & 10 & 0.795 \\
2 & 0.172 & 11 & 0.832 \\
3 & 0.277 & 12 & 0.876 \\
4 & 0.290 & 13 & 0.982 \\
5 & 0.317 & 14 & \\
6 & 0.879 & & \\
7 & 0.948 & $B a m H I$ & 0.420 \\
8 & & 1 & 0.481 \\
\hline SalI & & 2 & \\
1 & 0.183 & & \\
\hline
\end{tabular}

a The map coordinate for each restriction endonuclease site is given as a fraction of the length of the P22 genome, $41.6 \mathrm{~kb}(1)$, where the origin of the coordinate system is at pac (4). The EcoRI, HindIII, Sall, and BamHI cleavage sites are numbered in order of map location. Site locations were reported previously (4). The PstI sites were mapped by A. Siegel, R. Deans, and E. Jackson (unpublished experiments). The coordinate for the PstI site 1 was adjusted to agree with unpublished data of $\mathrm{S}$. Casjens.

ordered previously. The plating efficiencies of three different $10^{-}$am alleles on $\mathrm{Su}^{-}$ hosts carrying various cloned P22 fragments show that there is both a PstI and a SalI cleavage site in gene 10 . The map order of the three $10^{-}$am mutations shown in Fig. 1 was inferred from the known map order of these restriction targets. The same type of analysis was used in ordering gene 16 alleles as shown in Fig. 1.

This map generated from the marker rescue experiments (Fig. 1) extends our previous results (4) and is the most complete and detailed description now available of the physical location of P22 genes in the regions 0 to 0.555 and 0.795 to 1.0 . Several physical gene maps of segments of these regions have been made previously by other approaches. Chan and Botstein (9) constructed a physical map of a portion of the genome near the attachment site from electron microscopic studies of insertions, deletions, and substitutions. Weinstock and Botstein (6) correlated genetic and physical maps in the interval between genes 20 and 9 by measuring the distances between $\operatorname{Tn} 1$ insertions and sites of cleavage by $E c o$ RI or $B a m H I$ in the region. Conditional lethal mutations in gene 9 have been mapped

9 overlaps BamHI site 1 (see Fig. 1). Early region genes between $a 1$ and 18 were placed on the map by restriction endonuclease digestion of phages carrying insertions, deletions, or substitutions as follows: int and erf, Youderian and Susskind (23); 2A, c2, c1, Jackson et al. (1), Deans and Jackson (2), Poteete et al. (29). Genes $c 3$, sieB, and 17 are located between genes 24 and erf by recombination frequency data (14). The order of these three genes is uncertain. 
TABLE 3

Rescue of ant Alleles from Cloned P22 Restriction Fragments ${ }^{a}$

\begin{tabular}{llllll}
\hline & \multicolumn{5}{c}{ Source of lysate } \\
\cline { 2 - 6 } & $\begin{array}{c}\text { NK1345/ } \\
\text { pRR322 }\end{array}$ & $\begin{array}{l}\text { NK1345/ } \\
\text { pP22-306 }\end{array}$ & $\begin{array}{l}\text { NK1345/ } \\
\text { pP22-320 }\end{array}$ & $\begin{array}{c}\text { NK1345/ } \\
\text { pP22-351 }\end{array}$ & $\begin{array}{l}\text { NK1345/ } \\
\text { pP22-201 }\end{array}$ \\
\hline ant ${ }^{-}$am 16 & $1.1 \times 10^{-7}$ & $1.1 \times 10^{-7}$ & $4.0 \times 10^{-7}$ & $1.0 \times 10^{-5}$ & $1.6 \times 10^{-7}$ \\
ant $^{-}$am 19 & $2.7 \times 10^{-7}$ & $3.3 \times 10^{-7}$ & $4.0 \times 10^{-7}$ & $8.3 \times 10^{-6}$ & $1.9 \times 10^{-7}$ \\
Wild type & 1.2 & 0.8 & 0.7 & 0.6 & 0.7 \\
\hline
\end{tabular}

${ }^{a}$ Cultures of the Su- strain S. typhimurium NK1345 $\left(\mathrm{LT} 2 \mathrm{r}^{-} \mathrm{m}^{+}\right.$gal $^{+}$rif $^{\mathrm{R}}$ nal $\mathrm{c}^{\mathrm{R}} \mathrm{cys}^{-}$, obtained from N. Kleckner) containing the hybrid plasmids indicated were infected while growing exponentially in $L$ broth (24) at $37^{\circ}$ with one of the indicated P22 strains $(8,13)$ at a multiplicity of five phage per cell. The infected culture was incubated with aeration at $37^{\circ}$ for $25 \mathrm{~min}$, and then chloroform was added to complete lysis. The lysate was then titered on DB5057 (8) and NK1345. Ant phage will grow on both hosts. Ant phage grow on NK1345 but not DB5057 (8). The ratio of the titer on DB5057 to the titer on NK1345 is given for each lysate. Both ant ${ }^{-}$am alleles rescue from the hybrid plasmid which contains the P22 EcoRI/HindIII h fragment (NK1345/pP22-351), although the small size of this fragment (about 300 base pairs) limits the frequency of wild type recombinants obtained.

relative to deletion endpoints and the physical locations of some amber sites related to the size of amber fragments of gene 9 protein (15, P. B. Berget, G. Weinstock, and D. Botstein, manuscript in preparation). Each method of correlating physical and genetic maps has advantages for each particular application. The rescue of genetic markers from cloned restriction fragments is a convenient way to relate genetic markers in all regions of the chromosome to physical markers which are present in all P22 strains. Many different alleles of a gene can be quickly mapped once a set of cloned fragments is available, and both essential and nonessential genes can be placed relative to restriction targets. When genes are located relative to restriction enzyme targets, cleavage at those sites can be used to produce fragments of the chromosome of known genetic content.

Comparison of the P22 recombination frequency map with the physical maps available previously had shown that the late gene region is expanded on the genetic map $(1,4,6,11)$. The more detailed physical gene map of Fig. 1 further defines the magnitude and extent of the distortion. Genes 3, 2, 1, 8, and 5 occupy over $40 \%$ of the recombination frequency map (11) but less than $20 \%$ of the physical map (Fig.
1). The expansion of the genetic map in the vicinity of genes $3,2,1,8$, and 5 is probably a consequence of the P22 headful packaging mechanism which generates circularly permuted, terminally redundant linear DNA molecules (16-18). Only a limited set of permuted molecules are packaged, since ends of mature linears fall predominantly in the region 0.03 to 0.15 on the physical map $(1,4,16)$. Because the permuted molecules are terminally redundant, genes in the region 0 to 0.15 will appear in heterozygotes in a genetic cross at high frequency. When the terminally redundant heterozygotic chromosome infects the next host cell, an essential early step in the replicative cycle is recombination between redundant ends (19), thereby providing opportunity for generating recombinant genomes. The finding that genes $3,2,1,8$, and 5 are expanded on the genetic map relative to the physical map is therefore further confirmation of the location of the packaging origin, the direction of sequential headful packaging, and the number of sequential headfuls inferred from other data $(16,20-22)$.

A composite physical map of the complete P22 genome can be generated by correlating the map of Fig. 1 with other physical and genetic mapping data for the region 0.550 to 0.795 . Figure 2 depicts the 
approximate physical location of all P22 genes of known function. In addition, the physical map of genes for some proteins not essential for lytic growth which are encoded in the region 0.42 to 0.63 has been reported (23). The function of most of these proteins is not yet known, and the genes encoding them are not included on the map. The relative distances between genetic markers is different on the physical map of Fig. 2 than on previous P22 maps $(6,11,14)$, and is a more accurate representation of gene placement on the phage chromosome. This map will be useful since genes throughout the chromosome have been located relative to physical markers that can be used to generate defined chromosomal fragments.

\section{ACKNOWLEDGMENTS}

We thank David Botstein, Miriam Susskind, Peter Berget, Nancy Kleckner, and Tony Poteete for generously supplying the $S$. typhimurium and PZ2 strains. We also thank Miriam Susskind, Peter Berget, and Sherwood Casjens who provided access to unpublished data. This work was supported by Grant number AI-12369 from the National Institutes of Health. JER was supported by training Grant number 1-T32GM-07544-03 awarded by the National Institutes of Health.

\section{REFERENCES}

1. JACKSON, E. N., Miller, H. I., and ADAMS, M. L., J. Mol. Biol. 118, 347-363 (1978).

2. DEANS, R. J., and JACKSON, E. N., Virology 95, 359-372 (1979).

3. Weinstock, G. M., PH.D. thesis, Massachusetts Institute of Technology (1977).

4. Chisholm, R. L., DeANS, R. J., JaCKson, E. N., JACKSON, D. A., and RUTILA, J. E., Virology 102, 172-189 (1980).

5. Deans, R. J., Ph.D. thesis, University of Michigan (1979).

6. Weinstock, G. M., and Botstein, D., Virology 106, 92-99 (1980).
7. Levine, M., TRUesdell, S., RamakrishnaN, T., and Bronson, J. J., J. Mol. Biol. 91, 421-438 (1975).

8. BOTSTEIN, D., LEW, K. K., JARVIK, V., and SWANSON, C. A., J. Mol. Biol. 91, 439-462 (1975).

9. Chan, R. K., and Botstein, D., Virology 49, 257267 (1972).

10. Gough, M., and ScotT, J., Virology 50, 603-605 (1972).

11. BotSTEIN, D., ChaN, R. K., and WADDELL, C. H., Virology 49, 268-282 (1972).

12. Poteete, A. R., and KING, J., Virology 76, 725739 (1977).

13. Susskind, M. M., J. Mol. Biol. 138, 685-713 (1980).

14. Susskind, M. M., and Botstein, D., Microbiol. Rev. 42, 385-413 (1978).

15. SMith, D. H., BeRget, P. B., and KING, J., Genetics 96, 331-352 (1980).

16. Tye, B. K., Huberman, J. A., and Botstein, D., J. Mol. Biol. 85, 501-537 (1974).

17. RhoAdes, M., MachatTte, L. A., and Thomas, C. A. JR., J. Mol. Biol. 37, 21-40 (1968).

18. ISRAEL, V., Virology 106, 100-106 (1980).

19. Botstein, D., and MatZ, M. J., J. Mol. Biol. 54, 417-440 (1970).

20. JACKSON, E. N., JACKSON, D. A., and DEANS, R. J., J. Mol. Biol. 118, 365-388 (1978).

21. Weaver, S., and Levine, M., J. Mol. Biol. 118, 389-411 (1978).

22. ChAN, R. K., Ph.D. thesis, Massachusetts Institute of Technology (1974).

29. Youderian, P., and SusSkind, M. M., Virology 107, 270-282 (1980).

24. SMITH, H. O., and Levine, M., Virology 31, 207216 (1967).

25. Young, B. G., Fukazawa, Y, and Hartman, P. E., Virology 23, 279-283 (1964).

26. RAO, R. N., and SMITH, H. O., Virology 36, 328330 (1968).

27. Youderian, P., and Susskind, M. M., Virology 107, 258-269 (1980).

28. Winston, F., and Botstein, D., manuseript in preparation.

29. Poteete, A. R., Ptashne, M., Ballivet, M., and EISEN, H., J. Mol. Biol. 137, 81-91 (1980). 